\title{
Comparison of in vivo airway responsiveness and in vitro smooth muscle sensitivity to methacholine in
}

\section{man}

\author{
JA ROBERTS, D RAEBURN, IW RODGER, NC THOMSON
}

From the Department of Respiratory Medicine, Western Infirmary; and the Department of Physiology and Pharmacology, University of Strathclyde, Glasgow

ABSTRACT Airway responsiveness to methacholine varies between normal people and is increased in patients with asthma. The importance of airway smooth muscle sensitivity in determining in vivo responsiveness is unknown. We have examined this question by comparing in vivo airway responsiveness with in vitro airway smooth muscle sensitivity to methacholine in 10 patients undergoing thoracic surgery. In vivo responsiveness was determined by administration of inhalations of doubling concentrations of methacholine. Results were expressed as the provocation concentration (PC) causing a decrease in forced expiratory volume in one second of $20 \%$ $\left(\mathrm{PC}_{20} \mathrm{FEV}_{1}\right)$, specific airway conductance of $35 \%\left(\mathrm{PC}_{35} \mathrm{sGaw}\right)$, and maximal expiratory flow at $35 \%$ vital capacity, measured for the partial $\left(\dot{\mathrm{V}}_{35(\mathrm{p})}\right)$ and complete $\left(\dot{\mathrm{V}}_{35(\mathrm{c})}\right)$ flow volume curves, of $35 \%\left(\mathrm{PC}_{35} \mathrm{~V}_{35(\mathrm{p})} ; \mathrm{PC}_{35} \mathrm{~V}_{35(\mathrm{c})}\right)$. In vitro airway smooth muscle sensitivity was determined from specimens obtained at thoracotomy. Log dose-response curves to methacholine were constructed and the concentration causing a $50 \%$ maximum contraction $\left(\mathrm{EC}_{50}\right)$ was derived. There were differences between patients for both in vivo airway responsiveness and in vitro smooth muscle sensitivity to methacholine. There were no significant relationships between the in vivo and in vitro measurements. The results suggest that factors other than solely the sensitivity of smooth muscle must determine in vivo airway responsiveness to methacholine.

Airway responsiveness to the cholinergic agonist methacholine varies between normal people ${ }^{1}$ and is increased in patients with asthma. ${ }^{2}$ The reduction in airway calibre induced by this agonist involves the contraction of airway smooth muscle. ${ }^{3}$ Thus the difference in responsiveness to methacholine in normal and asthmatic subjects may be related to variations between individuals in their airway smooth muscle sensitivity to this agent. Alternatively, the variability between subjects in responsiveness may be a consequence of differences in the neural or humoral control (or both) of airway smooth muscle. Previous studies have found that in vitro airway smooth muscle sensitivity to a cholinergic agonist varies between individuals, ${ }^{345}$ but the in vitro values were not related to in vivo measurements of responsiveness.

In this study we have compared in vivo airway

Address for reprint requests: Dr JA Roberts, Department of Respiratory Medicine, Western Infirmary, Glasgow G11 6NT.

Accepted 15 May 1984 responsiveness to methacholine with in vitro sensitivity of preparations of isolated bronchi taken from the same patient at thoractomy, to determine whether variation in responsiveness to methacholine may be explained by differences in the sensitivity of airway smooth muscle to the drug.

\section{Methods}

\section{PATIENTS}

Ten patients scheduled to undergo lobectomy or pneumonectomy were studied (table). Eight patients had operable bronchial carcinoma, one had a tuberculoma, and one had a solitary metastasis from a renal clear cell carcinoma. All had been smokers but at the time of study two had stopped smoking more than a year previously. Four patients fulfilled the Medical Research Council's definition of chronic bronchitis. ${ }^{6}$ Only one patient (No 2) gave a history of wheezy dyspnoea and hay fever. Five were atopic as indicated by a weal of $2 \mathrm{~mm}$ or more 
in response to prick skin testing with one or more of seven common allergens (house dust; Dermatophagoides pteronyssinus; cat; dog; feathers; mixed grass pollen; Aspergillus fumigatus), although only three patients had raised specific IgE concentrations. Four patients were on regular drug treatment before surgery (table). In patient 2 no inhaled salbutamol or oral aminophylline was administered within 12 hours of methacholine challenge or surgery. Each patient was premedicated with papaveretum and hyoscine. Anaesthesia was induced with either Althesin or thiopentone sodium and maintained with nitrous oxide and halothane. Various neuromuscular and anaesthetic blocker drugs were given. The trachea was intubated and the lungs were ventilated artificially.

All patients gave informed consent and the experimental protocol was approved by the Western Infirmary ethical committee.

\section{IN VIVO MEASUREMENTS}

Airway resistance and thoracic gas volume were measured in a constant volume body plethysmograph (Fenyves and Gut) by the methods of Du Bois et al. ${ }^{7}$ The results were expressed in terms of specific airways conductance (sGaw), which is the reciprocal of airways resistance per litre of thoracic gas volume. The mean of eight values recorded was taken as sGaw. Partial and complete expiratory flow volume (PEFV and CEFV) curves were obtained with a heated pneumotachograph having integration of flow and recorded on an X-Y recorder (HewlettPackard 7041A). The flow-volume curves were obtained in the following manner. After a period of normal tidal breathing each patient expired maximally from end tidal inspiratory volume to residual volume (RV) to obtain the PEFV curve. When RV was reached the patient inspired to total lung capacity (TLC) and expired maximally to RV to obtain the CEFV curve. From the CEFV curve the forced expiratory volume in one second $\left(\mathrm{FEV}_{1}\right)$ and forced vital capacity (FVC) were obtained. The volume corresponding to $65 \%$ below total lung capacity (TLC) was obtained from the mean FVC of at least five baseline curves. Maximum expiratory flows at this lung volume were measured from the partial $\left(\dot{\mathrm{V}}_{35(\mathrm{p})}\right)$ and complete $\left(\dot{\mathrm{V}}_{35(\mathrm{c})}\right)$ flow volume curves for baseline and subsequent curves-that is, curves were matched at TLC in order to compare flow rates. Body plethysmographic measurements always preceded flow volume recordings.

Routine preoperative pulmonary function tests were performed as follows: spirometry was measured on a water sealed spirometer (Godart); static lung volumes were determined by the helium dilution technique and from spirometric readings; single breath transfer factor for carbon monoxide (TLCO) was determined by the method of Ogilvie et al.$^{8}$ Predicted normal values were taken from Cotes. ${ }^{9}$

Methacholine inhalation tests were carried out with a modification of the method described by Cockcroft et al..$^{10}$ Aerosols were generated with the same Wright nebuliser by air at $50 \mathrm{lb} / \mathrm{in}^{2}(345 \mathrm{kPa})$ at a flow rate of $81 \mathrm{~min}^{-1}$ to give an output of 0.15

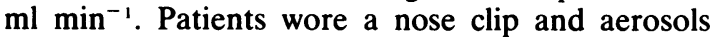
were inhaled by tidal breathing through a loose

Table Characteristics of the 10 patients: respiratory function, atopy, smoking, and clinical features

\begin{tabular}{|c|c|c|c|c|c|c|c|c|c|c|c|c|c|c|}
\hline \multirow{2}{*}{ Patient No } & \multirow{2}{*}{$\begin{array}{l}\text { Age } \\
(y)\end{array}$} & \multirow[t]{2}{*}{ Sex } & \multirow{2}{*}{$\begin{array}{l}\text { Height } \\
(\mathrm{cm})\end{array}$} & \multicolumn{2}{|l|}{$F E V_{1}$} & \multirow{2}{*}{$\begin{array}{l}V C \\
\left(\%^{*}\right)\end{array}$} & \multirow{2}{*}{$\begin{array}{l}R V \\
\left(\%{ }^{*}\right)\end{array}$} & \multirow{2}{*}{$\begin{array}{l}T L C O \\
\left(\%{ }^{*}\right)\end{array}$} & \multirow[t]{2}{*}{ Atopy } & \multirow{2}{*}{$\begin{array}{l}\text { Current } \\
\text { smoker }\end{array}$} & \multicolumn{2}{|c|}{ Diagnosis } & \multirow[t]{2}{*}{ Medication } & \multirow{2}{*}{ 爻 } \\
\hline & & & & $\overline{(l)}$ & $\left(\%^{*}\right)$ & & & & & & Surgical & other & & \\
\hline 1 & 50 & $\mathbf{M}$ & 170 & 3.92 & 123 & 122 & 95 & 61 & + & + & $\mathbf{s}$ & $\begin{array}{l}\text { Chronic } \\
\text { bronchitis, } \\
\text { - HPOA }\end{array}$ & $\begin{array}{l}\text { Indomethacin } \\
\text { Dextropropoxyph } \\
\text { Paracetamol }\end{array}$ & กอำ \\
\hline 2 & 43 & $\mathbf{M}$ & 177 & 1.67 & 45 & 64 & 108 & 68 & + & + & $\mathbf{s}$ & $\begin{array}{l}\text { Chronic } \\
\text { bronchitis, } \\
\text { wheezy } \\
\text { dyspnoea }\end{array}$ & $\begin{array}{l}\text { Salbutamol (inhal } \\
\text { Aminophylline (o } \\
\text { Temazepam } \\
\text { Levorphan } \\
\text { Metaclopramide }\end{array}$ & ledp \\
\hline 3 & 49 & $\mathbf{F}$ & 155 & $2 \cdot 18$ & 96 & 95 & 148 & 77 & - & + & 1 & $\begin{array}{l}\text { Peripheral } \\
\text { vascular } \\
\text { disease }\end{array}$ & Inositol & గ \\
\hline $\begin{array}{l}4 \\
5\end{array}$ & $\begin{array}{l}63 \\
64\end{array}$ & $\begin{array}{l}\mathbf{M} \\
\mathbf{M}\end{array}$ & $\begin{array}{l}178 \\
169\end{array}$ & $\begin{array}{l}2 \cdot 91 \\
2 \cdot 85\end{array}$ & $\begin{array}{r}92 \\
106\end{array}$ & $\begin{array}{r}98 \\
133\end{array}$ & $\begin{array}{l}115 \\
135\end{array}$ & $\begin{array}{l}75 \\
55\end{array}$ & $\begin{array}{l}+ \\
+\end{array}$ & $\begin{array}{l}+ \\
+\end{array}$ & $\begin{array}{l}\mathbf{s} \\
\mathbf{a}\end{array}$ & $\begin{array}{l}\text { Chronic } \\
\text { bronchitis }\end{array}$ & & $\begin{array}{l}N \\
\tilde{\omega} \\
\tilde{V}\end{array}$ \\
\hline $\begin{array}{l}6 \\
7 \\
8 \\
9\end{array}$ & $\begin{array}{l}66 \\
61 \\
62 \\
56\end{array}$ & $\begin{array}{l}\mathbf{F} \\
\mathbf{F} \\
\mathbf{M} \\
\mathbf{M}\end{array}$ & $\begin{array}{l}165 \\
153 \\
173 \\
180\end{array}$ & $\begin{array}{l}1 \cdot 64 \\
1 \cdot 55 \\
2 \cdot 32 \\
2 \cdot 76\end{array}$ & $\begin{array}{l}81 \\
81 \\
81 \\
79\end{array}$ & $\begin{array}{l}69 \\
97 \\
88 \\
94\end{array}$ & $\begin{array}{l}100 \\
140 \\
102 \\
118\end{array}$ & $\begin{array}{r}106 \\
115 \\
114 \\
79\end{array}$ & $\begin{array}{l}+ \\
- \\
-\end{array}$ & $\begin{array}{l}+ \\
+ \\
+ \\
+\end{array}$ & $\begin{array}{l}\text { c } \\
1 \\
\mathbf{s} \\
\mathbf{s}\end{array}$ & $\begin{array}{l}\text { Chronic } \\
\text { bronchitis }\end{array}$ & Chlorthalidone & 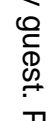 \\
\hline 10 & 69 & $\mathbf{M}$ & 168 & $2 \cdot 82$ & 110 & 97 & 60 & 141 & - & - & $\mathbf{t}$ & & & \\
\hline
\end{tabular}

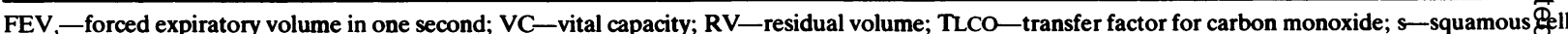

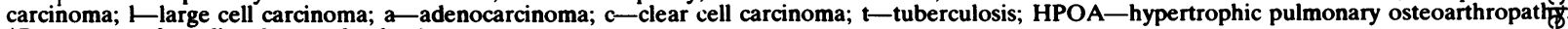
*Percentage of predicted normal value." 
fitting facemask. Buffered normal saline was inhaled first, followed by doubling concentrations of phosphate buffered methacholine $(2-128 \mathrm{mg} / \mathrm{ml})$. Each inhalation was for 2 minutes at 12 minute intervals. Before the first inhalation sGaw and five PEFV and CEFV curves were recorded. From 1.5 minutes after each inhalation responses were measured by sGaw and two PEFV and CEFV curves. Inhalations were continued until the $\mathrm{FEV}_{1}$ had fallen by $20 \%$ or more, or until the maximal concentration had been administered. Log dose-response curves were plotted and results were expressed as the provocation concentration causing a $20 \%$ decrease in $\mathrm{FEV}_{1}$ $\left(\mathrm{PC}_{20} \mathrm{FEV}_{1}\right)$, a $35 \%$ decrease in sGaw $\left(\mathrm{PC}_{35} \mathrm{sGaw}\right)$, and a $35 \%$ decrease in $\dot{\mathrm{V}}_{35(\mathrm{p})}\left(\mathrm{PC}_{35} \dot{\mathrm{V}}_{35(\mathrm{p})}\right)$ and in

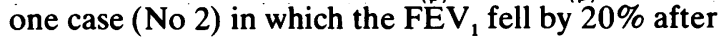
inhalation of the lowest concentration of methacholine, extrapolated PC values were calculated. The $\mathrm{PC}_{20} \mathrm{FEV}_{1}$ was not measured in patient No 1.

\section{IN VITRO MEASUREMENTS}

Bronchial tissue was obtained immediately after removal at thoracotomy. Similar sized samples of second to sixth order bronchi were dissected from macroscopically normal tissue and then stored overnight at $4^{\circ} \mathrm{C}$ in well oxygenated Krebs-Henseleit solution of the following composition (mmol/l): $\mathrm{NaCl} 118, \mathrm{KCl} 4 \cdot 7, \mathrm{MgSO}_{4} 7 \mathrm{H}_{2} \mathrm{O} 1 \cdot 2, \mathrm{KH}_{2} \mathrm{PO}_{4} 1 \cdot 2$, $\mathrm{CaCl}_{2} 6 \mathrm{H}_{2} \mathrm{O} 2 \cdot 5, \mathrm{NaHCO}_{3} 25$, glucose $11 \cdot 7$. The next day rings of bronchi were dissected out and sectioned to produce transverse strips of tissue that were suspended under a resting tension $1.5-2.0 \mathrm{~g}$ in $20 \mathrm{ml}$ organ baths containing Krebs-Henseleit solution maintained at a constant temperature of $37^{\circ} \mathrm{C}$. The tissues were allowed to equilibrate for 60 minutes, after which they were washed three times. Changes in tension were recorded isometrically with Grass FT03C forced displacement transducers and displayed on a Grass (model 7) polygraph.

After equilibration the tissue was exposed twice to near maximally effective concentrations of methacholine $(10 \mu \mathrm{mol} / \mathrm{l}$, determined in preliminary experiments) at 30 minute intervals to gauge the magnitude, normality, and reproducibility of the contractions. A cumulative concentration-effect curve was then constructed by adding increasing concentrations of methacholine (from $10 \mathrm{nmol} / \mathrm{l}$ to $1 \mathrm{mmol} / \mathrm{l}$ ) until a maximum response was obtained. Each addition of the drug was made at the peak of effect produced by the preceding concentration. In each experiment the concentrations of methacholine that produced a $20 \%\left(\mathrm{EC}_{20}\right)$ and $50 \%\left(\mathrm{EC}_{50}\right)$ maximal contraction were calculated from the graphically displayed data. Additionally, the maximum tension generated was determined and expressed in $g$ ten- sion. At least four bronchial strips from each patient were tested and mean values for $\mathrm{EC}_{20}, \mathrm{EC}_{50}$, and maximum tension generated determined.

In preliminary experiments no significant difference was found between the sensitivity of bronchial strips taken from second and from sixth order bronchi.

\section{STATISTICAL ANALYSIS}

In the comparison of in vivo and in vitro results correlation coefficients were calculated from linear regression by the method of least squares analysis. PC results were analysed under a natural logarithm transformation. The level of statistical significance was set at $\mathrm{p}<0.05$.

\section{Results}

IN VIVO

Airway responsiveness to methacholine varied between individual patients (fig 1). There were significant correlations $(\mathrm{p}<0.05)$ between $\mathrm{PC}_{20}$ $\mathrm{FEV}_{1}$ and $\mathrm{PC}_{35} \dot{\mathrm{V}}_{35(\mathrm{c})}(\mathrm{r}=0.64), \mathrm{PC}_{35} \mathrm{sGaw}$ and

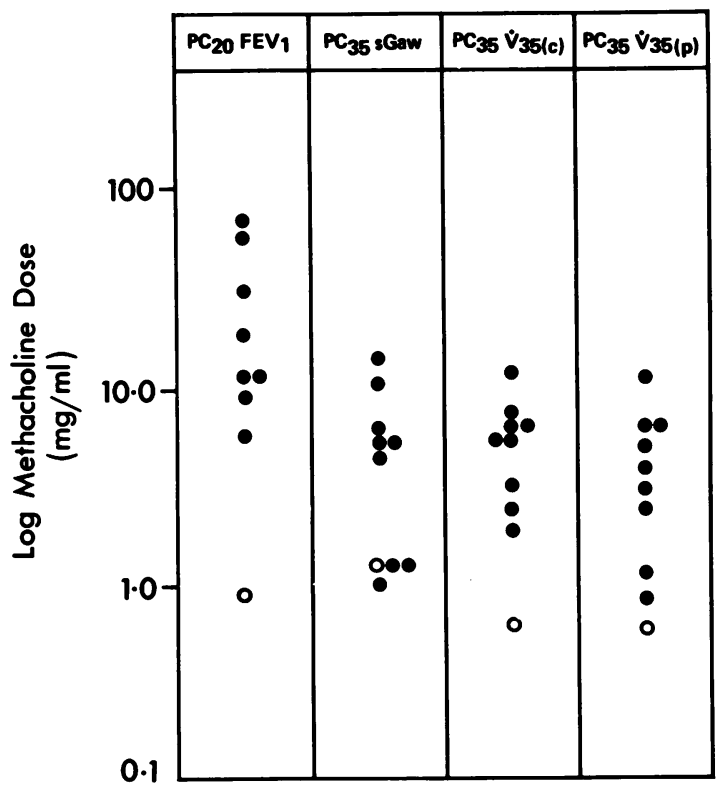

Fig 1 Airway responsiveness of ten patients to inhaled methacholine, one of whom (O) had symptoms of wheezy dyspnoea. Results were expressed as the provocation concentration $(P C)$ causing a decrease in forced expiratory volume in one second of $20 \%\left(P C_{20} F E V\right)$, specific airway conductance of $35 \%\left(P C_{35} s G a w\right)$, and maximal expiratory flow at $35 \%$ vital capacity, measured from the complete $\left(\dot{V}_{35(c)}\right)$ and partial $\left(\dot{V}_{35(p)}\right)$ flow volume curves, of $35 \%$ $\left(P C_{35} V_{35(c)} ; P C_{35} \nabla_{35(p)}\right)$. 
$\mathrm{PC}_{35} \dot{\mathrm{V}}_{35(\mathrm{p})}(\mathrm{r}=0.65)$, and $\mathrm{PC}_{35} \dot{\mathrm{V}}_{35(\mathrm{p})}$ and $\mathrm{PC}_{35} \dot{\mathrm{V}}_{35(\mathrm{c})}$ $(\mathrm{r}=0.74)$.

Baseline $\mathrm{FEV}_{1}$ (expressed as a percentage of the predicted normal value) correlated with $\mathrm{PC}_{35} \mathrm{~V}_{35(\mathrm{p})}$ $(\mathrm{r}=0.71) ; \mathrm{p}<0.05)$ but was not significantly related to the other measurements of in vivo responsiveness $\left(\mathrm{PC}_{20} \mathrm{FEV}_{1} \quad(\mathrm{r}=0.59) ; \quad \mathrm{PC}_{35} \mathrm{sGaw}\right.$ $\left.(\mathrm{r}=0.32) ; \mathrm{PC}_{35} \dot{\mathrm{V}}_{35(\mathrm{c})}(\mathrm{r}=0.53)\right)$. There was no significant correlation between baseline sGaw (absolute value) and measurements of in vitro sensitivity.

\section{IN VITRO}

The sensitivity to methacholine of diffierent bronchial strips from individual patients assessed by $\mathrm{EC}_{50}$ was highly reproducible $(r=0.87)$. In contrast, there were appreciable differences in the sensitivity to methacholine of bronchial strips prepared from different patients as indicated by the range of $\mathrm{EC}_{20}$ and $\mathrm{EC}_{50}$ values obtained. The mean (SEM) $\mathrm{EC}_{20}$ value from all preparations was $0.41(0.12) \mu \mathrm{mol} / \mathrm{l}$ (range 0.029-0.93 $\mu \mathrm{mol} / \mathrm{l}$ ) and the mean $\mathrm{EC}_{50}$ value was $3.9(1.0) \mu \mathrm{mol} / \mathrm{l}$ (range $0.41-8.1 \mu \mathrm{mol} / \mathrm{l}$ ). The mean maximum tension generated was $1.44(0.29) \mathrm{g}$ (range $0 \cdot 37-3.59 \mathrm{~g}$ ).

\section{COMPARISON OF IN VIVO AND IN VITRO}

RESPONSIVENESS TO METHACHOLINE

There were no significant correlations between any of the measurements of in vivo responsiveness and in vitro smooth muscle sensitivity to methacholine. The lack of relationship is illustrated for $\mathrm{PC}_{20} \mathrm{FEV}$,

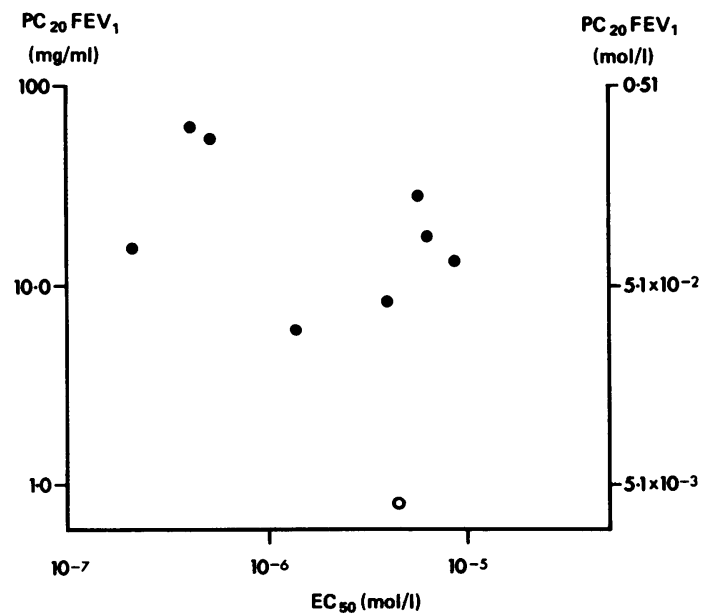

Fig 2 Comparison of in vivo airway responsiveness to methacholine expressed as $P C_{20} F E V$, and in vitro smooth muscle sensitivity expressed as $E C_{50}(\mathrm{~mol} / \mathrm{l})(r=-0.35 ; p$ $>0.05$ ). against $\mathrm{EC}_{50}$ (fig 2), for $\mathrm{PC}_{35} \mathrm{sGaw}$ against $\mathrm{EC}_{50}$ (fig 3), and for $P_{35} \dot{V}_{35(c)}$ and $P_{35} \dot{V}_{35(p)}$ against $\mathrm{EC}_{50}$ (fig 4). Furthermore, there were no significant relationships between in vivo measurements and maximum tension generated.

The patient who had a history of wheezy dyspnoea and the lowest $\mathrm{PC}_{20} \mathrm{FEV}_{1}$ (No 2) did not show increased in vitro smooth muscle sensitivity to methacholine $\left(\mathrm{EC}_{50} 4.0 \mu \mathrm{mol} / \mathrm{l}\right)$, nor was the maximum tension generated increased $(1.41 \mathrm{~g})$.

\section{Discussion}

This study demonstrated no significant relationship between measurements of in vivo airway responsiveness to methacholine and in vitro sensitivity of isolated bronchial smooth muscle obtained from the same patients. Previous studies have examined either in vivo human airway responsiveness ${ }^{2}$ or in vitro human airway smooth muscle sensitivity to this pharmacological stimulus ${ }^{35}$ but not in vivo and in vitro responses in the same subjects.

Several factors might have influenced in vivo and in vitro measurements. Unlike in studies carried out in vitro, the dose of methacholine administered to airway smooth muscle in vivo cannot be determined accurately. It is dependent on the technique of aerosol generation, particle size, and breathing pattern. 112 In this study methacholine was administered via a Wright nebuliser and by the same method in each individual. Thus although the dose reaching the lung was unknown it should have been

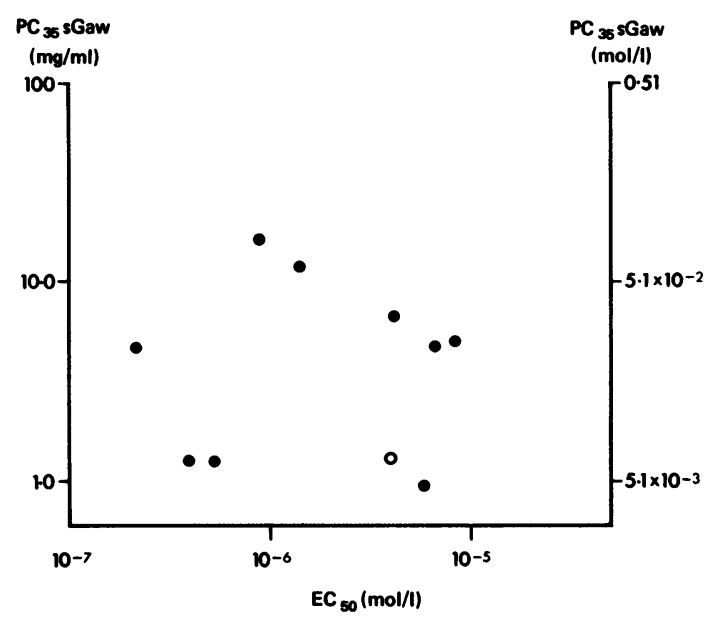

Fig 3 Comparison of in vivo airway responsiveness to methacholine expressed as $P C_{35}$ SGaw and in vitro smooth muscle sensitivity expressed as $E C_{50}(r=-0.03 ; p>0.05)$. 

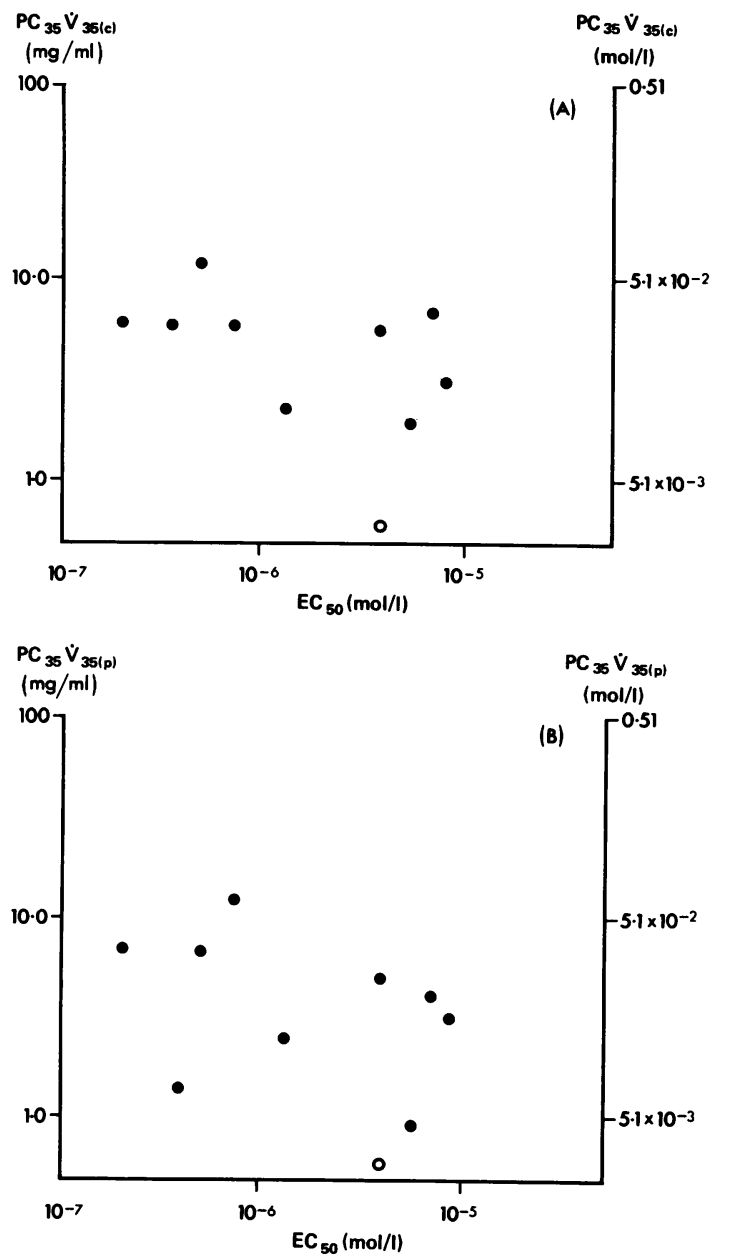

Fig 4 Comparison of in vivo airway responsiveness and in vitro smooth muscle sensitivity to methacholine. Panel (a) $P C_{35} \dot{V}_{35(c)}$ against $E C_{50}(r=-0.33 ; p>0.05)$. Panel $(b)$ $P C_{35} \dot{V}_{35(p)}^{35(c)}$ against $E C_{50}(r=-0.30 ; p>0.05)$.

similar in all patients. The site of deposition of the drug within the airways might also influence the response obtained. The patients we studied were current smokers or ex-smokers and had a degree of small airway disease. A Wright nebuliser produces a diffuse pattern of deposition within the lung, ${ }^{12}$ but in individuals with small airway narrowing the aerosol may be deposited to a greater extent in the larger airways. We examined tissue samples from second to sixth order bronchi. In vitro results therefore reflected the sensitivity of larger airways. Comparison of $\mathrm{EC}_{50}$ and $\mathrm{PC}_{35}$ sGaw, a measurement of large airway responsiveness, ${ }^{13}$ might have been expected to show the closest relationship if any had existed.
Nevertheless, a relationship between in vivo airway responsivesness and in vitro sensitivity of more peripheral airway smooth muscle cannot be excluded from this study. In addition, the access of a bronchoconstrictor drug to airway smooth muscle, and thus the response to that drug may be affected by airway permeability. ${ }^{14}$ But although airway permeability was found to be increased in smokers ${ }^{15}$ no relationship was found between the level of airway permeability and airway responsiveness. ${ }^{16}$

It is impossible to produce a full dose-response curve to a bronchoconstrictor agent in man, so the position on the in vitro curve at which in vivo responses are measured is unclear. If, for example, the in vivo measurements fell on the lower nonlinear region of the full in vitro log dose-response curve, then in vivo and in vitro measurements might not be correlated even if in vivo responsiveness was determined by smooth muscle sensitivity. We found no relationship, however, between in vivo responsiveness and a measure of in vitro sensitivity taken from the lower part of the dose-response curve $\left(\mathrm{EC}_{20}\right)$.

Baseline airway calibre or tone or both may be an important determinant of airway responsiveness, ${ }^{17}$ because resistance is inversely proportional to the fourth power of the radius when flow is laminar. In

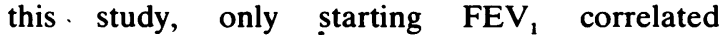
significantly with $\mathrm{PC}_{35} \dot{\mathrm{V}}_{35(\mathrm{p})}$ suggesting that the variation in responsiveness to methacholine between patients was not due only to differences in baseline airway calibre. Possibly small but important differences in baseline airway calibre or tone may not have been detected by the methods used, or differences between subjects in the distribution of resistance within the airways might have influenced in vivo measurements of responsiveness.

Variations in upper airway calibre may also effect airway resistance. Higenbottam ${ }^{18}$ demonstrated that aerolised histamine produced a variable reduction in laryngeal calibre with an associated fall in $\mathrm{FEV}_{1}$. If, as he proposed, this was due to stimulation of vagal sensory endings methacholine would not be expected to produce a similar effect. ${ }^{19}$

In normal subjects inhalation to total lung capacity can reduce the effect of induced bronchoconstriction..$^{20}$ This would affect $\mathrm{FEV}_{1}$ and $\dot{\mathrm{V}}_{35(\mathrm{c})}$ but not sGaw or $\dot{\mathrm{V}}_{35(\mathrm{p})}$ measurements. As none of these measurements correlated with in vitro sensitivity it is unlikely that this bronchodilatation is an important factor in the lack of relationship between in vivo and in vitro measurements.

To minimise the effect of preoperative and perioperative drugs on the response of smooth muscle to methacholine, all tissues were washed twice on removal, stored for 16 hours in Krebs- 
Henseleit solution, and then washed again both before and after suspension in the organ bath. The effects of atropine, a drug pharmacologically similar to hyoscine, can be removed from in vitro preparations within minutes by washing. ${ }^{2122}$ Brink et al ${ }^{4}$ have shown no difference in the sensitivities of fresh and stored human airway smooth muscle preparations.

We also found no significant relationship between in vivo responsiveness to methacholine and the maximum tension generated by bronchial strips from each patient. Maximum tension may be related to the quantity of smooth muscle present in each bronchial strip which ideally should be measured but this is technically difficult. In an attempt to correct for variations in the amount of tissue and hence smooth muscle present, the maximum force generated was corrected for the wet weight of tissue in each strip. This was compared with the indices of in vivo responsiveness but no relationship was found.

This study has considered only one agonist, methacholine, which may be acting on muscarinic receptors on airway smooth muscle, ${ }^{3}$ submucosal glands, ${ }^{23}$ presynaptic receptors on sympathetic nerves, ${ }^{24}$ and mast cells. ${ }^{25}$ The bronchoconstrictor response may therefore be due to mechanisms other than solely a direct effect on airway smooth muscle.

Patients selected for this study were due to undergo thoracic surgery. Most had bronchial carcinoma and were current smokers or ex-smokers and only one showed in vivo hyperresponsiveness, with a $\mathrm{PC}_{20} \mathrm{FEV}_{1}$ below $8 \mathrm{mg} / \mathrm{ml}^{2}{ }^{2}$ In these patients our findings suggest that smooth muscle sensitivity alone does not determine in vivo airway responsiveness to methacholine.

The cause of airway hyperresponsiveness in asthma is unknown. It could be due to an abnormality in airway smooth muscle or to the neural or humoral control of the airways (or both).$^{26-28}$ In this study only one patient had some features of asthma. Although we were able to study him only over a short period and were unable to assess the airway resonse to a "trial of steroids," he had symptoms of wheezy dyspnoea, showed a $14 \%$ increase in FEV after bronchodilator, had Curschmann's spirals in his sputum, and had an increased response to inhaled methacholine. The airway smooth muscle strips from this patient, however, were not hypersensitive to methacholine. This finding, if confirmed in other patients with definite asthma, would indicate that airway hyperresponsiveness is not attributable to an increased sensitivity to methacholine at the receptor level (as indicated by the $\mathrm{EC}_{50}$ value). In support of this finding with methacholine, Dahlen and coworkers ${ }^{29}$ recently reported that the response of bronchial strips to histamine, prostaglandin $F_{2_{\alpha}}$ and leukotreine $\mathrm{D}_{4}$ were similar in normal and asthmatic subjects.

\section{Addendum}

Since our original submission of this paper, Vincenc and coworkers ${ }^{30}$ have reported that they found no relationship between in vivo and in vitro responses to histamine in a group of non-asthmatic patients undergoing thoracic surgery.

We wish to thank Mr MA Turner and Mr A Faichney, cardiothorac surgeons, Western Infirmary, for allowing us access to their patients. We are indebted for support from the Asthma Research Council, Fisons Ltd, PSGB, and the Wellcome Trust.

\section{References}

' Parker CD, Bilbo RE, Reed CE. Methacholine aerosol as tests for bronchial asthma. Arch Intern Med 1965; 115:452-8.

${ }^{2}$ Hargreave FE, Ryan G, Thomson NC, et al. Bronchial responsiveness to histamine or methacholine in asthma: measurement and clinical significance. $J$ Allergy Clin Immunol 1981;63:347-55.

${ }^{3}$ Hawkins DF, Schild HD. The action of drugs on isolated human bronchial chains. $\mathrm{Br} J$ Pharmacol 1951;6:682-90.

${ }^{4}$ Brink C, Grimaud C, Guillot C, Orehek J. The interaction between indomethacin and contactile agents on human isolated airway muscle. Br J Pharmacol 1980;69:383-8.

${ }^{5}$ Goldie RG, Paterson JW, Wale JL. Pharmacological responses of human and porcine lung parenchyma, bronchus and pulmonary artery. Br J Pharmacol 1982;76:515-21.

${ }^{6}$ Medical Research Council. Definition and classification of chronic bronchitis for clinical and epidemiological purposes. Lancet 1965; i:775-9.

${ }^{7}$ Du Bois AB, Botelho SY, Comroe JH. A new method for measuring airway resistance in man using a body plethysmograph; values in normal subjects and patients with respiratory disease. J Clin Invest 1956;35:327-35.

${ }^{8}$ Ogilvie CM, Forster RE, Blakemore WS, Morton JW. A standardized breath holding technique for the clinical measurement of the diffusing capacity of the lung for carbon monoxide. J Clin Invest 1957;36:1-7.

${ }^{9}$ Cotes JE. Lung function: principles and application in medicine. Oxford: Blackwell Scientific Publications, 1975.

${ }^{10}$ Cockcroft DW, Killian DN, Mellon JJA, Hargreave FE. Bronchial reactivity to inhaled histamine: a method and clinical survey. Clin Allergy 1977; 7:235-43.

" Brain JD. Factors influencing deposition of inhaled particles. In: Hargreave FE, ed. Airway reactivity. Mississauga: Astra Pharmaceuticals Canada Ltd, 1980:316. 
12 Ryan G, Dolovich MB, Obminski G, et al. Standardization of inhalation provocation tests: influence of nebulizer output particle size, and method of inhalation. J Allergy Clin Immunol 1981;67:156-61.

${ }^{13}$ Pride NB. The assessment of airflow obstruction. Role of measurements or airways resistance and of tests of forced expiration. $\mathrm{Br} J$ Dis Chest 1971;65:135-69.

${ }^{14}$ Hogg JC. Bronchial mucosal permeability and its relationship to airway hyperreactivity. $J$ Allergy Clin Immunol 1981;67:421-5.

15 Jones JG, Mint BD, Lawler P, Hylands G, Crawley JCW, Veall N. Increased alveolar epithelial permeability in cigarette smokers. Lancet $1980 ; 1: 66-8$.

${ }^{16}$ Kennedy S, Pare P, Elwood K, Wiggs B, Hogg JC. Lung epithelial permeability and airway reactivity in smokers and non smokers. Am Rev Respir Dis 1983;127:252.

${ }^{17}$ Benson MK. Bronchial hyperreactivity. Br J Dis Chest 1975;69:227-39.

${ }^{18}$ Higenbottam T. Narrowing of glottis opening in humans associated with experimentally induced bronchoconstriction. J Appl Physiol 1980;49:403-7.

19 Vidruk EH, Hahn HL, Nadel JA, Sampson SR. Mechanisms by which histamine stimulates rapidly adapting receptors in dog lungs. J Appl Physiol 1977;43:397402.

${ }^{20}$ Fish JE, Ankin MG, Kelly JF, Peterman VI. Regulation of bronchomotor tone by lung inflation in asthmatic and nonasthmatic subjects. J Appl Physiol 1981;50:1079-86.
${ }^{21}$ Clark AJ. Acetylcholine and atropine. J Physiol 1926;61:545-56.

22 Blattner R, Classen HG, Dehnert H, Doring HJ. Experiments on isolated smooth muscle preparations. Frieiberg: Hugo Saches Elektronik KG, 1978.

${ }^{23}$ Nadel JA. Regulation of fluid and mucous secretions in airways. J Allergy Clin Immunol 1981;67:417-20.

24 Westfall TC. Neuroeffector mechanisms. Ann Rev Physiol 1980;42:383-97.

${ }^{25}$ Kaliner M, Orange RP, Austen KF. Immunological release of histamine and slow reacting substances of anaphylaxis from human lung. Enhancement by cholinergic and alpha adrenergic stimulation. $J$ Exp Med 1972; 136:556-67.

26 Widdicombe JG. Regulation of tracheobronchial smooth muscle. Physiol Rev 1963;43:1-37.

${ }^{27}$ Richardson JB. Nerve supply to the lungs. Am Rev Respir Dis 1979;119:785-802.

28 Thomson NC. Neurogenic and myogenic mechanisms of nonspecific bronchial hyperresponsiveness. Eur J Respir Dis 1983;64:206-12.

${ }^{29}$ Dahlen SE, Hanson G, Hedqvist P, Bjórck T, Granstrom E, Dahlen B. Allergen challenge of lung tissue from asthmatics elicits bronchial contraction that correlates with the release of leukotrienes $C_{4}, D_{4}$ and $E_{4}$. Proc Natl Acad Sci 1983;80:1712-6.

${ }^{30}$ Vincenc KS, Black JL, Yan K, Armour CL, Donnelly $\mathrm{PD}$, Woolcock AJ. Comparison of in vivo and in vitro responses to histamine in human airways. $A m R e v$ Respir Dis 1983;128:875-9. 